\title{
Occurrence of L-Phenylalanine Ammonia-lyase Activity in Peach Fruit during Growth ${ }^{\dagger}$
}

\author{
By Shohei Aoki, ${ }^{*}$ Chuji Araki, Katsuyoshi Kaneko \\ and Osamu Katayama** \\ Shinjo Branch, Food Research Institute, Ministry of Agriculture \\ and Forestry, Shinjo, Yamagata, Japan \\ Received September 24, 1970
}

L-Phenylalanine ammonia-lyase (PAL) (EG 4.3.1.5) catalyzing the conversion of L-phenylalanine to trans-cinnamic acid was first demonstrated in barley by Koukol and Conn." Since then, many studies have been made on PAL in various higher plants such as sliced or black rot infected sweet potato root, ${ }^{21}$ potato tuber disks, ${ }^{3 !}$ buckwheat stem, ${ }^{4}$ bamboo shoot ${ }^{5 /}$ and others. And it has been indicated that this enzyme is widely distributed in the plant kingdom and plays an important role as a key enzyme in the biosynthesis of phenolic compounds.

Recently, the presence of PAL in fruit tissues has been also studied by several workers. Riov et al. have observed that a higher PAL activity is induced in grapefruit and orange peel by gamma irradiation, ${ }^{6}$ and that there

+ This work was presented at the Annual Meeting of the Agricultural Chemical Society of Japan, Fukuoka, April 4, 1970.

* Present Address: Takasaki Radiation Chemistry Research Establishment, Japan Atomic Energy Research Institute, Takasaki, Gunma.

* Present Address: Food Research Institute, Ministry of Agriculture and Forestry, Koto-ku, Tokyo.

1) J. Koukol and E. E. Conn, J. Biol. Chem., 236, 2692 (1961).

2) T. Minamikawa and I. Uritani, J. Biochem., 57, $678(1965)$.

3) M. Zucker, Plant Physiol., 40, 779 (1965).

4) S. Yoshida and M. Shimokoriyama, Bot. Mag. Tokyo, 78, 14 (1965).

5) T. Higuchi, Agr. Biol. Chem., 30, 667 (1966).

6) J. Riov, S. P. Monselise and R. S. Kahan, Radiation Botany, 8, 463 (1968). is a close correlation between ethylene production and PAL activity in grapefruit peel." Maier et $a l .{ }^{81}$ have reported that a direct relationship exists between PAL activity and the rate of naringenin glycoside accumulation in developing grapefruit. The authors have demonstrated in the previous paper ${ }^{9 !}$ that PAL activities occur in Japanese chestnut and strawberry fruit and in apple fruit peel.

This paper deals with the occurrence of PAL in peach fruit tissues at various growing stages. This study was undertaken as a step to investigate the changes in metabolic activities of the shikimic acid pathway in fruit tissues.

Plant materials. The peach fruit (Prunus persica) variety Okubo (white-fleshed species) grown in an orchard at Tendo city, Yamagata, in 1969 was used in this study. The fruits were picked five times from the same tree during growing process. The dates of picking and the average weight of fruit, which was determined for ten fruits, are shown in Table I. The fruits picked were separated as much as possible into the sections of peel, pulp and core tissue, and each tissue was used for preparing acetone powder. The core

7) J. Riov, S. P. Monselise and R. S. Kahan, Plant Physiol, 44, 631 (1969).

8) V.P. Maier and S. Hasegawa, Phytochem., 9, $139(1970)$.

9) S. Aoki, C. Araki, K. Kaneko and O. Katayama, Nippon Shokuhin Kogyo Gakkaishi, 17, 507 (1970). 
tissues were soft in fruits picked before June 20 , but became too hard to cut after July 7 . Therefore, they were left out from the sample after this date. The fruit on August 19 was commercially mature.

Extraction of enzyme. Fifty $\mathrm{g}$ portions of each tissue were cut into small pieces and blended with $200 \mathrm{ml}$ of cold acetone $\left(-20^{\circ} \mathrm{C}\right.$ ) in a blendor for $2 \mathrm{~min}$. The homogenate was filtered on a Buchner funnel by suction, and the residue was washed several times with cold acetone and dried in a vacuum desiccator at $0^{\circ} \mathrm{C}$ overnight. The yield of acetone powder in each tissue is shown in Table I. The acetone powder showed no significant loss of PAL activity for at least 6 months during storage in a freezer at $-20^{\circ} \mathrm{C}$. For the preparation of enzyme solution, $1 \mathrm{~g}$ of acetone powder was suspended in $40 \mathrm{ml}$ of $0.05 \mathrm{M}$ sodium borate buffer ( $\mathrm{pH} 8.8$ ) at approximately $3^{\circ} \mathrm{C}$ for $1 \mathrm{hr}$, and the suspension was cleared by centrifugation at $7000 \times g$ for $10 \mathrm{~min}$ at $0^{\circ} \mathrm{C}$. The supernatant obtained was used as the crude enzyme solution. The crude enzyme solution was also relatively stable. When the crude enzyme solution was stored at $0^{\circ} \mathrm{C}$, only about $20 \%$ of the activity originally present was gradually lost in the course of 7 days.

Assay of PAL activity. The activity of PAL in the crude enzyme solution was determined spectrophotometrically by measuring trans-cinnamic acid formed according to the method of Koukol and Conn." The reaction mixture consisted of $1 \mathrm{ml}$ of $10^{-2} \mathrm{M} \mathrm{L}$-phenylalanine, $2 \mathrm{ml}$ of $0.05 \mathrm{M}$ sodium borate buffer ( $\mathrm{pH} 8.8$ ) and $1 \mathrm{ml}$ of enzyme solution. To the blank test was added distilled water in place of phenylalanine. The mixture was incubated for $3 \mathrm{hr}$ at $30^{\circ} \mathrm{C}$. The reaction was stopped by addition of $0.1 \mathrm{ml}$ of $6 \mathrm{~N}$ hydrochloric acid. The acidified mixture was extracted once with $5 \mathrm{ml}$ of peroxide-free ethyl ether, the ether phase was pipetted, and the ether was evaporated to dryness at room temperature under an air stream by a fan. The residue was dissolved in $4 \mathrm{ml}$ of $0.05 \mathrm{M}$ sodium hydroxide and the optical density at $268 \mathrm{~m} \mu$ was measured with a Hitachi Model 124 spectrophotometer. The enzyme activity was expressed in $\mathrm{m} \mu$ moles of trans-cinnamic acid formed per $g$ of fresh weight of tissue per $3 \mathrm{hr}$ under the condition described above.

Determination of anthocyanin concentration. The relative concentration of anthocyanin was determined on the peel and pulp tissue of the sample on August 19. Anthocyanin was extracted from $2 \mathrm{~g}$ of the tissue with $50 \mathrm{ml}$ of $1 \%$ hydrochloric acid in methanol for $30 \mathrm{~min}$ at room temperature. As shown in Table I, the concentration of anthocyanin was expressed by the optical density at $525 \mathrm{~m} \mu$ in this methanolic solution.

Identification of reaction product. The product of enzyme reaction was identified as transcinnamic acid by ultraviolet absorption spectrum and paper chromatography. The ultraviolet absorption spectrum of the reaction product was identical with that of authentic trans-cinnamic acid in $0.05 \mathrm{M}$ sodium hydroxide. Paper chromatography was carried out by onedimentional ascending method on Toyo Roshi No. $51 \mathrm{~A}$ filter paper with the following three solvent systems: $n$-propanol-conc. ammonia $(7: 3, v / v)$ (I), ethanol-conc. ammonia-water $(80: 4: 16, \mathrm{v} / \mathrm{v})(\mathrm{II})$, and $2 \%$ acetic acid (III). The spots on the chromatogram were detected under an ultraviolet light at $254 \mathrm{~m} \mu$ with a Mitsumi ultraviolet lamp. The $R f$ values of the reaction product were also identical with those of the authentic sample. They were (I) 0.79 , (II) 0.79 , and (III) 0.62 .

Effect of $p H$ on enzyme activity. As shown in Fig. 1, the optimum $\mathrm{pH}$ of the enzyme reaction was found to be around 8.8 which was similar to that of the enzyme obtained from barley stem ${ }^{1 \prime}$ or sweet potato root. ${ }^{2 !}$ The enzyme was active in the alkaline range of $\mathrm{pH}$ examined. 
Table I. OCcurrence of L-Phenylalanine Ammonia-lyase Activity in Different Parts of Peach Fruit Tissues at Various Growing Stages

\begin{tabular}{|c|c|c|c|c|c|c|c|}
\hline \multicolumn{2}{|c|}{$\begin{array}{c}\text { Dates } \\
\text { of } \\
\text { picking }\end{array}$} & \multirow{2}{*}{$\begin{array}{l}\text { Weight } \\
\text { of } \\
\text { fruit }{ }^{a)} \\
(g) \\
5\end{array}$} & \multirow{2}{*}{\multicolumn{2}{|c|}{$\begin{array}{l}\text { Parts of } \\
\text { fruit } \\
\text { used } \\
\mathrm{A}+\mathrm{B}+\mathrm{C}\end{array}$}} & \multirow{2}{*}{$\begin{array}{l}\text { Yields of } \\
\text { acetone } \\
\text { powder } \\
(0.0) \\
7.5\end{array}$} & \multirow{2}{*}{$\begin{array}{c}\text { Enzyme } \\
\text { activities }^{b} \text {, } \\
63\end{array}$} & \multirow{2}{*}{$\begin{array}{c}\text { Concentrations } \\
\text { of } \\
\text { anthocyanin } \\
\text { (OD }\end{array}$} \\
\hline JUN & 5 & & & & & & \\
\hline \multirow[t]{3}{*}{ JUN 2} & 20 & 23 & & $A+B+C$ & 6.4 & 102 & - \\
\hline & & & & $A+B$ & 8.2 & 56 & - \\
\hline & & & & $\mathrm{C}$ & 5.7 & 260 & - \\
\hline \multirow[t]{2}{*}{ JUL } & 7 & 38 & & $A+B$ & 6.5 & 0 & - \\
\hline & & & & B & 5.0 & 0 & - \\
\hline \multirow{2}{*}{\multicolumn{2}{|c|}{$A L G \quad 1$}} & 75 & & A & 8.8 & 0 & - \\
\hline & & & & B & 5.3 & 0 & - \\
\hline \multirow[t]{4}{*}{$\mathrm{AUG}$} & 19 & 190 & & Reddish & 9.3 & 67 & 2.62 \\
\hline & & & $\mathrm{A}$ & Yellowish & 9.5 & 0 & 0.08 \\
\hline & & & $B$ & Reddish & 4.4 & 40 & 0.15 \\
\hline & & & B & Whitish & 4.5 & 0 & 0 \\
\hline
\end{tabular}

A: Peel, B: Pulp, C: Core

a) Average for ten fruits

b) trans-Cinnamic acid formed mumoles $/ \mathrm{g}$ of tissue $/ 3 \mathrm{hr}$ at $30^{\circ} \mathrm{C}, \mathrm{pH} 8.8$

For enzyme assay and anthocyanin measurement, see the text.

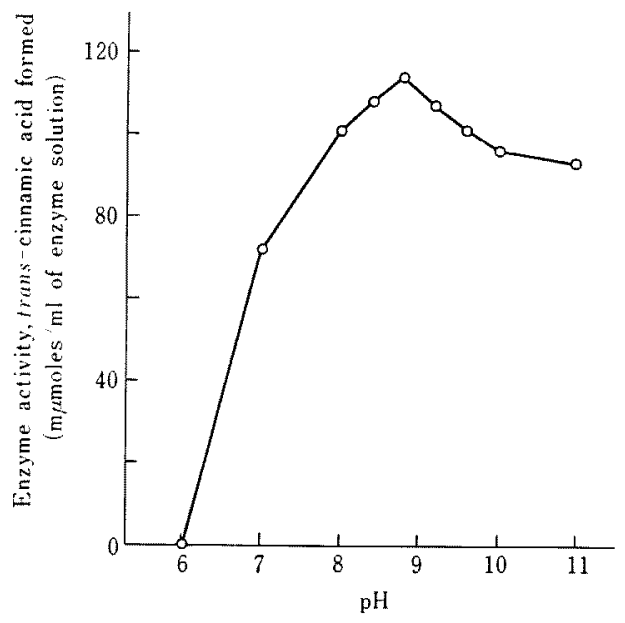

FIG. 1. Effect of pH on L-Phenylalanine Ammonialyase Activity in Peach Fruit Tissue.

The crude enzyme solution prepared from core tissue on June 20 was used. A reaction mixture contained $1 \mathrm{ml}$ of $10^{-2} \mathrm{M} \mathrm{L}$-phenylalanine, $2 \mathrm{ml}$ of $0.05 \mathrm{M}$ sodium borate buffer of indicated $\mathrm{pH}$, and $1 \mathrm{ml}$ of enzyme solution, and was incubated for $3 \mathrm{hr}$ at $30^{\circ} \mathrm{C}$. For enzyme assay, see the text.
Occurrence of PAL activity in peach fruit tissue. PAL activities in different parts of peach fruit tissue at various growing stages are summarized in Table I. In an early growing stage, PAL activity was found to occur in both peel and pulp tissue, and in particular, the core tissue on June 20 just before the beginning of lignification showed a higher activity. In the period following early growing stage, there were no detectable activities in both peel and pulp tissue. However, in the peel and pulp tissue of mature fruit, the activity was detected only in the reddish parts containing anthocyanin.

The facts that the young fruit shows the high level of PAL activity and the level decreases gradually with the growth of fruit have been also demonstrated in grapefruit by Maier et al. ${ }^{81} \quad$ Furthermore, Yoshida et al. ${ }^{4}$ have observed that PAL activity is always high in the top portion of buckwheat stem and decreases progressively toward the lower portion, and that, however, it shows again a fairly high level in the basal portion where 
lignification is taking place. Similar results have been obtained in bracken stem by the authors. ${ }^{9 !}$ From these facts, it seemed that the development of PAL might be associated with the age of the cell. Higuchi ${ }^{51}$ has suggested that PAL should be formed increasingly after the completion of cell division and cell wall synthesis in young meristematic tissues.

Yoshida et al." and Higuchi ${ }^{51}$ have reported that PAL activity has developed in parallel with the lignification of tissue in buckwheat stem and bamboo shoot, respectively. This was also demonstrated in peach core tissue by the present study because the higher activity of PAL was detected in the core tissue on June 20 just before the beginning of lignification. That lignin is accumulated progressively in core tissue of peach fruit during growth has been already reported by Ryugo. ${ }^{10}$

In the present study, it was also observed that PAL activities occurred in the peel and pulp tissue containing anthocyanin. Similar

10) K. Ryugo, Proc. Amer. Soc. Hort. Sci., 80, 197 (1962). results have been obtained in strawberry fruit and apple fruit peel as reported in the authors' previous paper. ${ }^{91}$ These results suggest that PAL is also related to the formation of anthocyanin in fruit tissue. The participation of PAL for anthocyanin formation has been elucidated in buckwheat hypocotyls by Scherf et al., ${ }^{11}$ in strawberry leaf disks by Creasy, ${ }^{12}$ and in carrot aggregens by Sugano et al. ${ }^{131}$ respectively.

Although the test for L-tyrosine ammonialyase activity was carried out by the use of the reaction mixture containing L-tyrosine in place of L-phenylalanine, no activity was detected in the peach fruit tissues at every growing stage.

Acknowledgement. The authors wish to express their thanks to Dr. H. Shitomi, Shinjo Branch, Food Research Institute, Ministry of Agriculture and Forestry, for many helpful advices.

11) H. Scherf and M. H. Zenk, Z. Pfanzenphysiol, 56, 203 (1967).

12) L. L. Creasy, Phytochem., 7, 441 (1968).

13) N. Sugano and K. Hayashi, Bot. Mag. Tokyo, 81, 371 (1968). 